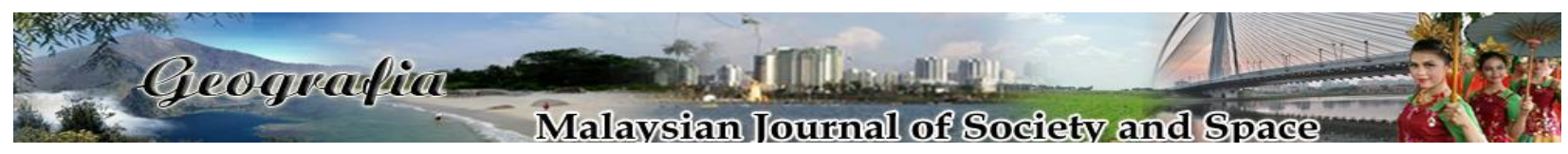

\title{
The role of Community-Based Disaster Preparedness and Response Team in building community resilience
}

\author{
Erni Suharini, Siti Asiah, Edi Kurniawan \\ Department of Geography, Faculty of Social Sciences, Universitas Negeri Semarang \\ Coresspondence: Erni Suhairini (email: erni.suharini@mail.unnes.ac.id)
}

Received: 05 April 2020; Accepted: 13 November 2020; Published: 29 November 2020

\begin{abstract}
The community and government of Kalipancur Village have realised and implemented the landslide disaster mitigation efforts known as Community-Based Disaster Preparedness and Response Team (SIBAT Team) as a part of the Disaster Risk Reduction Forums (FPRB) in Kalipancur Village. The purpose of this study was to determine the role of the SIBAT Team in implementing the resilience of the community of Kalipancur, especially the residents of RW 1 , who live in landslide-prone areas. The sample in this study consisted of the SIBAT Team and residence of Kalipancur Village from RW I that were chosen using proportional random sampling. Data collection techniques used were observation, tests, questionnaires, and interviews. The data analysis techniques used consisted of qualitative data analysis technique with interactive methods and quantitative data analysis with descriptive analysis technique. The results showed that the SIBAT Team has a big role in building community resilience in Kalipancur Village in disaster mitigation education and emergency response efforts. The magnitude of the role of the SIBAT Team is directly proportional to the high level of community resilience in all aspects of the Kalipancur community. This research exemplifies that the Community-Based Disaster Risk Reduction (CBDRR) program is a strategic effort in building community resilience. Therefore, the sustainability of the CBDRR program is a necessity, and collaboration between the government, NGOs, and communities that combines bottom-up and top-down approaches will be an effective effort to build community resilience.
\end{abstract}

Keywords: community resilience, disaster, Kalipancur village, landslide, SIBAT Team

\section{Introduction}

In addition to the economic and social potential that has an impact on the progress of the nation, Indonesia is also exposed to the potential of natural disaster (Kurniawan, Sriyanto, \& Syifauddin, 2019; Setyowati, 2017). This is due to its geographical position, geological features, and 
geomorphological processes (Cummins, 2017; Gorsel, 2013; Oktari, 2019). One of the cities or areas that is highly disaster-prone is Semarang City. According to data from the Indonesian Disaster Risk Index (IRBI) in 2013, Semarang City was ranked 96th out of 496 cities/districts in Indonesia and ranked $9^{\text {th }}$ out of 35 cities or regencies in Central Java. The area of Semarang is prone to disasters because it is located in the north of Mount Ungaran. The topography varies from flat, sloping, and steep slopes (Haryanto \& Suharini, 2009; Susanto \& Putranto, 2016). Based on the disaster report data listed on the official website of the Indonesian National Disaster Management Authority (BNPB), 117 disasters happened consisting of floods, tides, landslides, droughts, tornadoes, climate change, and tidal waves or abrasion in the period of 1990 to 2015. There are four types of disaster that often occur in Semarang City, namely flood, tidal flood, landslide, and drought (BPBD, 2015 in Pratiwi, Nugraha, Hani'ah, 2016).

Ngaliyan Sub-district is one of sub-districts which is prone to landslides, and Kalipancur Village is located within the sub-district. Based on the data from the Semarang City Regional Disaster Management Agency, there were at least 5 landslide disasters occurred in Kalipancur Village from 2014 to 2017. Many landslides occur at the peak of the rainy season, which happened at the beginning of the year. The landslide disaster caused hundreds of millions of rupiah in losses and destroyed the houses of Kalipancur's residents.

Based on the disaster risk in Kalipancur Village, disaster mitigation efforts are needed. In fact, people and the government of Kalipancur Village have realised and implemented the landslide disaster mitigation efforts. As it has been stated in Law No. 24 of 2007 on Disaster Management, the community and the government realise that disaster management efforts are a joint responsibility. The awareness of the government and the public on the importance of disaster mitigation is proven by the realisation of disaster mitigation efforts in Kalipancur Village which are implemented by the formation of Community-Based Disaster Preparedness and Response Team (SIBAT Team), as it becomes an essential part of Disaster Risk Reduction Forums (FPRB) in Kalipancur Village.

The SIBAT Team functions and acts as a companion as well as a mobilizer, mentor, instructor, and motivator that mobilizes the community in disaster preparedness activities or efforts, handling health, environmental, and other social problems (Parahita, Luthviatin, \& Istiaji, 2016). SIBAT Team is included in the program of The Disaster and Resilient Villages (KATANA), but the SIBAT Team itself is under the guidance of the Indonesian Red Cross Society or PMI (BNPB, 2012). The SIBAT team was formed in 2017 with a Decree number of 411.6/12/X /2017. The establishment of SIBAT is expected to be able to help the community in creating resilience in Kalipancur Village.

The implementation of disaster mitigation efforts by the SIBAT Team has strategic value in reducing vulnerability and increasing community resilience. The SIBAT team plays an important role in efforts to improve community-based preparedness and escalate the active role of the people of Kalipancur Village in mitigating against landslides. Many studies have proven the role of community-based disaster mitigation in increasing community resilience and capacity in dealing with disasters (Cui, Han, \& Wang, 2018; Pfefferbaum, et al., 2016). For this reason, researchers conducted research about the role of the SIBAT Team in enhancing community resilience in Kalipancur Village, Semarang City. 


\section{Literature review}

Basically, disaster is a phenomenon that occurs because the components of the trigger, hazards, and vulnerability work together systematically, causing risk to the community (Suharini, \& Kurniawan, 2015). For this reason, disaster mitigation efforts must be taken to reduce risk and vulnerability as well as increase community capacity and resilience so as to minimize the negative impact of disasters. Government Regulation Number 21 of 2008 on Disaster Management states that there are 3 stages in disaster mitigation, namely pre-disaster (disaster risk management, mitigation, and preparedness), during a disaster (emergency management), and post-disaster (recovery management).

In the context of disaster mitigation, the cooperation of all parties is required. The realization of this collaboration is the formation of Community Based Disaster Risk Reduction (CBDRR) in the form of Community-Based Disaster Preparedness Teams (SIBAT) in various regions in Indonesia, which was initiated by the cooperation between BNPB and PMI. The SIBAT team is one of forums for disaster risk reduction, and it functions and acts as a companion as well as a mobilizer, guide, extension agent, and motivator to empower the community in activities or efforts for disaster preparedness, handling of health impacts, environment, and other social problems as well as emergency tags in public.

The establishment of SIBAT Teams in various regions aims to build Disaster Resilient Village or Kelurahan Tangguh Bencana (KATANA). According to BNPB Head Regulation No. 1 of 2012, Disaster Resilient Village (KATANA) is defined as a village or sub-district that has the independent ability to adapt and face potential disaster threats, as well as to recover quickly from the adverse impacts of disasters. Disaster Resilient Village is a program of the Regional Disaster Management Agency (BPBD) as an effort to reduce disaster risk. The Disaster Resilient Village program aims to build community resilience through the realization of planning programs, institutions, strengthening legislation, funding, capacity building, and disaster management implementation.

\section{Method and research location}

The purpose of this study was to determine the role of the Community Based Disaster Preparedness Team (SIBAT TEAM) in realising the resilience of Kalipancur people, especially residents of community unit (RW) 1 who live in landslide-prone areas. This study used a mixed approach (qualitative-quantitative). Qualitative research was used to analyze the role of the SIBAT Team in building community resilience, while quantitative research was used to analyze the level of community resilience in facing landslides. Analysis of the role of the SIBAT Team in building community resilience consists of roles in socialization and emergency response plans, both before disasters, during disasters, and after disasters. The resilience of the people of Kalipancur is determined by various aspects of knowledge, attitudes, actions, policies, early warning, and community mobilization.

The population in this study consisted of The SIBAT Team and the community of Kalipancur Village from RW I. The technique for determining the number of samples used proportional random sampling, taking $10 \%$ of the total number of households in each neighborhood unit (RT) in RW I that is prone to landslides. In this research, the researcher obtained a sample of 59 respondents. Data collection techniques used were observation, tests, 
questionnaires, and interviews. To test the validity of the data, researchers used the triangulation method and used the product-moment correlation analysis and Cronbach Alfa. The data analysis techniques used consisted of qualitative data analysis techniques with interactive methods according to Miles and Huberman (1991) and quantitative data analysis with a descriptive analysis technique. The general flowchart of the research can be seen in Figure 1.

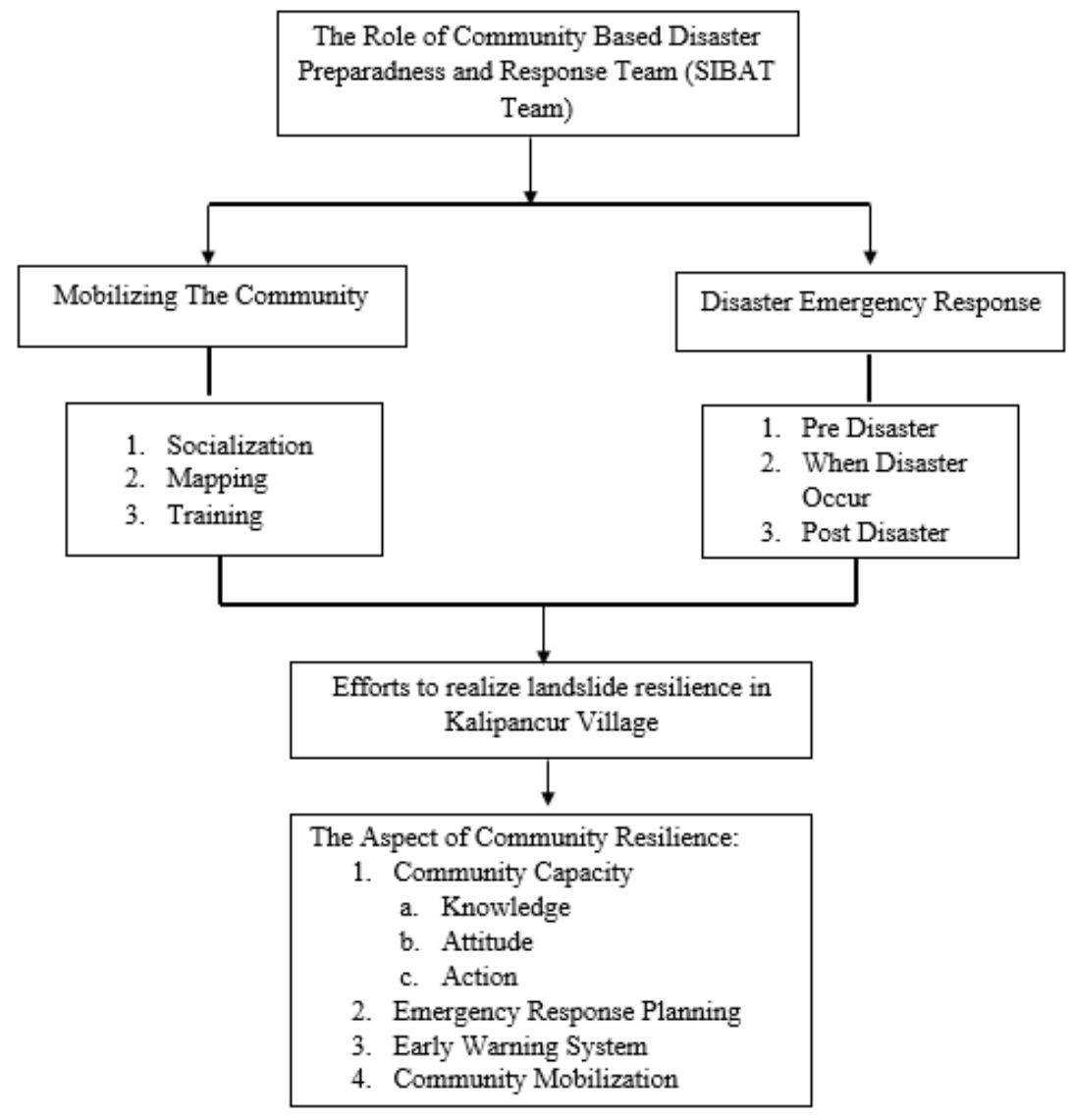

Figure 1. Flow chart of the research

Kalipancur Village is the easternmost area in Ngaliyan Sub-district, Semarang City. Kalipancur Village has three types of rock formations, namely the Alluvial Formation (Qtd), the Kalibeng Formation (Qa), and the Damar Formation (Tmpk). Alluvial (Qa) is a river plain consisting of gravel and sand. The Kalibeng Formation (QTd) is solid marl at the top filled with tuffaceous sandstone and limestone lumps at the bottom. The Damar Formation (QTd) is a sandstone consisting of feldspar and mafic mineral grains, local solids found by mollusks, and non-marine deposition sites.

The slope level of the Kalipancur Village varies greatly from flat to very steep. Some areas of Kalipancur Village with the steepest slopes are in RW I, RW II, and RW IV, which have a slope level of $35-55 \%$ (very steep) and $>55 \%$ (dangerously steep). The land use in Kalipancur Village is dominated by settlements. In addition, in Kalipancur Village, there are also quite large shrubs and fields. This land use affects the threat of landslides. Land that has a steep slope cannot be used as a residential area, but in reality, in Kalipancur Village, there are still many residents who build houses in areas that are very steep. This condition can be seen in the RW I, 
RW II, and RW IV areas. Therefore, these areas have a very high landslide risk index in Kalipancur Village. The map of the research location in Kalipancur Village, Ngaliyan Subdistrict, Semarang Citv can be seen in Figure 2.

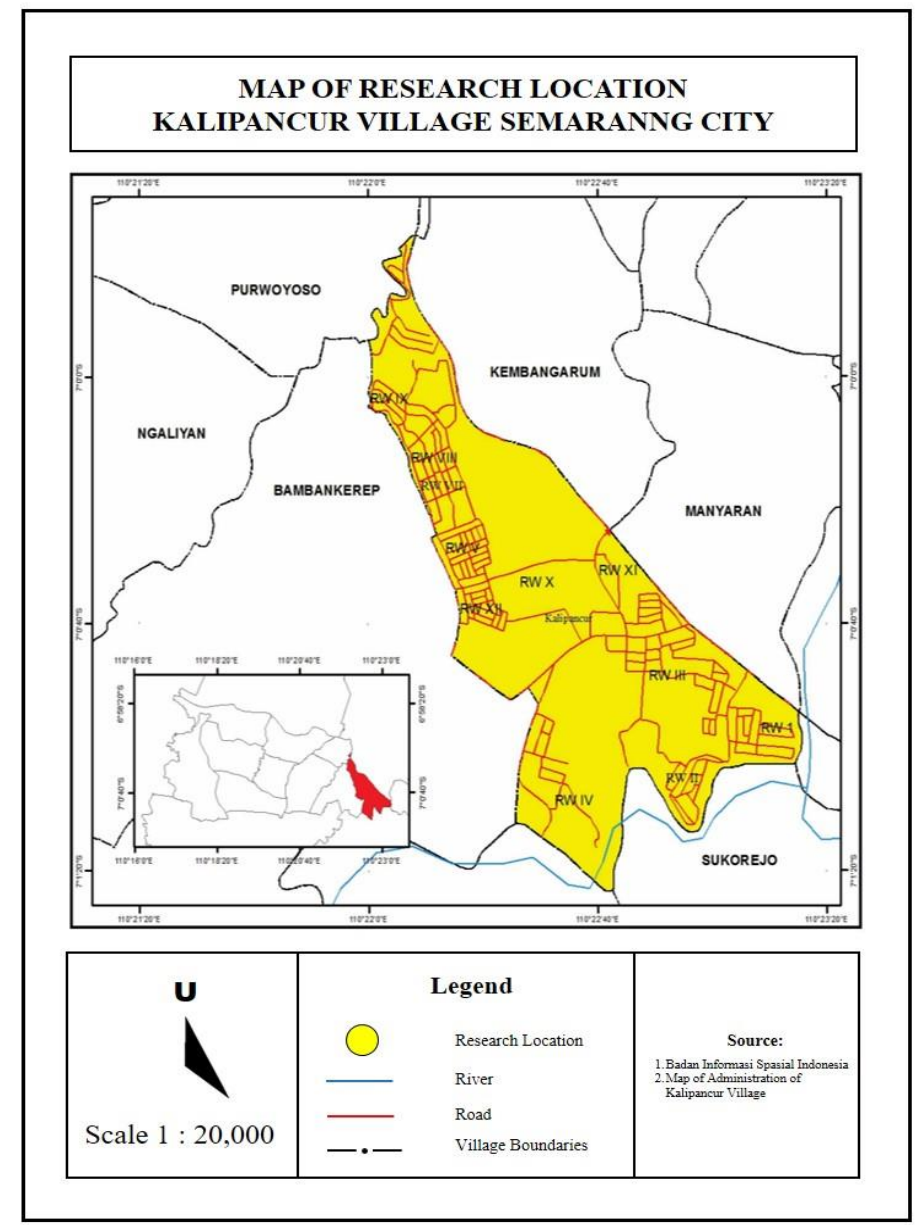

Figure 2. Map of Kalipancur Village, Ngaliyan Sub-district, Semarang City

\section{Results and findings}

\section{The role of Community-Based Disaster Preparedness and Response Team}

The Community-Based Disaster Preparedness Team (SIBAT Team) is one of the disaster risk reduction forums in Kalipancur village. It is one of the platforms or facilitators of community disaster risk reduction programs. Membership of the SIBAT Team takes into account the gender balance of $50 \%$ men and 50\% women coming from the Integrated Health Service Centre (Posyandu) elements, midwives, Family Welfare Empowerment (PKK), community empowerment institutions, youth organization, religious leaders, and community leaders. The organizational structure in the SIBAT Team consists of the chairman, secretary, treasurer, communication sector, shelter sector, logistics, and public kitchen. The SIBAT Team has a role in realizing the resilience of Kalipancur Village people, especially at RW I, in dealing with landslides. The SIBAT Team's roles are as follows: 


\section{a. Community Mobilisation}

Community mobilisation is a program to raise public awareness to participate in the planning, implementation, monitoring, evaluation, and sustainability of disaster-resilient community development programs. Community mobilisation program consists of some activities and events as follows:

1) Socialisation

This socialisation activity is intended to increase public knowledge, especially in the field of disaster mitigation. The socialization activity also aims to instill awareness in the community to always be aware of potential disasters so that they are active in taking preventive actions to minimize the occurrence of disasters.

2) The activity of Vulnerability Capacity Assessment (VCA) and participatory assessment

This vulnerability assessment activity was carried out by the SIBAT Team accompanied by the Indonesian Red Cross Society (PMI). This activity is carried out to assess the vulnerability of disasters in Kalipancur Village and assess existing problems. The vulnerability can be in the form of vulnerability from existing natural conditions and also concerns the social conditions. In addition, vulnerability also focuses on the availability of supporting facilities for the community.

3) Community-Based Disaster Preparedness training

Community-based disaster training aims to create a disaster-resilient community through the cultivation of knowledge and awareness in dealing with disasters from the pre-disaster stage, when there is a potential for disaster, during a disaster, and post-disaster. The training also involves efforts to minimize disaster risk to the community to increase the capacity of the community.

4) The formulation of the Disaster Risk Reduction Plan

The Coordination Meeting for the preparation of the Disaster Risk Reduction Plan aims to formulate the foundation, priorities, action plans and implementation mechanisms, and institutions in disaster risk reduction in Kalipancur Village. Disaster Risk Reduction Plan contains detailed arrangements for each party's responsibilities and can be adapted to existing social and geographical situations.

5) Alternative livelihood training

The alternative livelihood training activity was opened at RW 1 Kalipancur Village, initiated by the SIBAT Team. The training was in the form of making batik art. The batik training that was held by the SIBAT Team was attended by women from RW I residents.

6) First aid training

The first aid training was given to the community so that the community can help the victims when a disaster occurs. This first-aid training is held with the aim that the community has the ability to help in the first place when a disaster occurs so that it can reduce fatalities due to the impact of the disaster.

7) Reforestation or greening

The people of Kalipancur realised that landslides can be minimized through increasing the capacity of soil strength by planting trees, especially perennials. Tree planting is carried out by the SIBAT Team and local communities in sloping or prone areas to landslide disasters which cover RW 1 and some RW II areas. In addition to planting trees, the SIBAT Team and the community also take care of trees to maintain their sustainability.

8) The procurement and installation of evacuation route signs and gathering points 
One problem that can reduce the capacity of the community in dealing with disasters is the lack of facilities in disaster response. For this reason, the SIBAT Team conducted the procurement and installation of evacuation routes and gathering points to guide the community during the emergency response. The SIBAT Team worked closely with USAID, the International Federation of Red Cross and Red Representative Societies, Global Disaster and Preparedness Disaster, and the American Red Cross for funding.

9) Making and installing an Early Warning System

The Early Warning System (EWS) of the landslide was installed at prone-to-landslides points. Kalipancur Village has 5 technology-based landslides Early Warning System (EWS) tools. Early Warning System (EWS) will automatically sound when it detects a landslide will occur. The community will know when there will be a landslide.

10) The procurement of advice and infrastructure for emergency response.

The SIBAT Team has facilities and infrastructure that still need to be improved. Funding for the provision of these evacuation route signs is obtained in collaboration with USAID, the International Federation of Red Cross and Red Representative Societies, Global Disaster and Preparedness Disaster, and American Red Cross, as the SIBAT Team worked well with them.

b. When a potential disaster occurs

When a potential disaster occurs, the SIBAT Team carries out the task of preparedness efforts and disaster emergency response. In this situation, the SIBAT Team takes quick and appropriate action in order to reduce the risk of disaster and prepare for emergency response. This effort is carried out through observing disaster symptoms, analyzing the results of observing disaster symptoms, disseminating information about disaster warnings, and taking action by the community.

\section{c. When a disaster occurs}

When a disaster occurs, the SIBAT Team makes a disaster response effort quickly, precisely, and coordinated under the command of the Chief of Kalipancur Village. In this situation, the SIBAT Team and the government also conduct a quick and accurate assessment of the location of the damage and resources. After that, they search and rescue victims, give emergency assistance, and evacuation of victims, and funerals of victims who have died.

d. Obliged to assist the tasks and obligations of the Kalipancur Village Government

The SIBAT Team is required to assist the tasks and obligations of the Kalipancur Village Government. This obligation relates to activities from the pre-disaster stage, when there is a potential for disaster, when a disaster occurs, and during a post-disaster event.

\section{The Community Disaster Resilience in Kalipancur Village}

\section{a. Community Knowledge}

The level of community knowledge on landslides is very high (81.4\%). It could not be separated from the role of the SIBAT Team which has provided socialisation about landslide to the community. The level of knowledge can be seen in Table 1. 
Table 1. Community Knowledge Criteria

\begin{tabular}{ccccc}
\hline Score Interval & Percentage & Criteria & F & $\%$ \\
\hline $9-12$ & $76-100$ & Very high & 48 & 81,4 \\
$6-8$ & $51-75$ & High & 10 & 16,9 \\
$3-5$ & $26-50$ & Low & 1 & 1,7 \\
$0-2$ & $0-25$ & Very low & 0 & - \\
\hline & Total & & 59 & 100 \\
\hline
\end{tabular}

Source: Research Results, 2019

\section{b. Community Attitudes}

The attitudes of Kalipancur Village people at RW I are mostly good (69.5\%). The community is willing to accept, respond, respect, and be responsible. The community also feels that the landslide disaster that occurred in Kalipancur Village is a shared responsibility so all elements of the community need to play a role in efforts to prevent and manage landslides. The attitude of the community could be seen in Table 2 .

Table 2. Community Attitudes Criteria

\begin{tabular}{ccccc}
\hline Score Interval & Percentage & Criteria & F & $\%$ \\
\hline $22-28$ & $76-100$ & Very good & 41 & 69,5 \\
$16-21$ & $51-75$ & Good & 18 & 30,5 \\
$12-16$ & $26-50$ & Enough & 0 & - \\
$7-11$ & $0-25$ & Less good & 0 & - \\
\hline & Total & & 59 & 100 \\
\hline
\end{tabular}

Source: Research Results, 2019

\section{c. Community Actions}

Community actions show tangible evidence of knowledge and attitudes level possessed by someone. The action of the RW I community in terms of community disaster prevention is very high $(84.7 \%)$. Some of them are aware of what actions they need to take to reduce the risk of landslides. The attitude criteria could be seen in Table 3.

Table 3. Community Actions Criteria

\begin{tabular}{ccccc}
\hline Score Interval & Percentage & Criteria & F & $\%$ \\
\hline $5-6$ & $66-100$ & Very high & 50 & 84,7 \\
$3-4$ & $34-66$ & High & 9 & 15,3 \\
$0-2$ & $0-33$ & Low & 0 & - \\
& Total & & 59 & 100 \\
\hline
\end{tabular}

Source: Research Results, 2019 


\section{d. Policy}

Policy is an instrument of rules that have been planned by the government or by the SIBAT Team in efforts to mitigate landslides. The community knowledge about the policy of Kalipancur Village at RW I is high (62.7\%). This shows that they are already familiar with it, and willing to follow the policies and regulations made by the SIBAT Team and the government relating to the prevention of landslides. The policy criteria could be seen in Table 4 .

Table 4. Policy and regulatory Criteria

\begin{tabular}{ccccc}
\hline Score Interval & Percentage & Criteria & F & $\%$ \\
\hline $7-8$ & $76-100$ & Very high & 37 & 62,5 \\
$5-6$ & $51-75$ & High & 17 & 28,8 \\
$3-4$ & $26-50$ & Low & 5 & 8,5 \\
$0-2$ & $0-25$ & Very low & 0 & - \\
\hline & Total & & 59 & 100 \\
\hline
\end{tabular}

Source: Research Results, 2019

\section{e. Emergency Planning Response}

The emergency planning response for the community of Kalipancur Village at RW I is high $(100 \%)$. RW I people are aware of emergency response plans such as the location or place of evacuation, the evacuation route, and first aid kit or medicine. Emergency response criteria could be seen in Table 5 .

Table 5. Emergency Response Criteria

\begin{tabular}{ccccc}
\hline Score Interval & Percentage & Criteria & F & $\%$ \\
\hline $3-5$ & $49-100$ & High & 59 & 100 \\
$0-2$ & $0-49$ & Low & 0 & - \\
\hline Total & & 59 & 100 \\
\hline Source: Research Results, 2019 & &
\end{tabular}

\section{f. Early Warning System}

The community knowledge of Kalipancur Village at RW I on the early warning system and feeling the need to know how the Early warning system works is very high (91.5\%). The early warning system that has been available at RW 1 of Kalipancur Village and is already known by most people is a technology-based early warning system tool. The community feels the need to know how the early warning system works, and the community is willing to take responsibility for maintaining disaster instruments because it is a shared responsibility. Early warning system criteria can be seen in Table 6 . 
Table 6. Early Warning System Criteria

\begin{tabular}{ccccc}
\hline Score Interval & Percentage & Criteria & F & $\%$ \\
\hline $7-8$ & $76-100$ & Very high & 54 & 91,5 \\
$5-6$ & $51-75$ & High & 1 & 1,7 \\
$3-4$ & $26-50$ & Low & 4 & 6,7 \\
$0-2$ & $0-25$ & Very low & 1 & 1,7 \\
\hline & Total & & 59 & 100 \\
\hline
\end{tabular}

Source: Research Results, 2019

\section{g. Community Mobilization}

The Kalipancur Village community has a very high level of mobilization (89.8\%). The community wants to take part in activities organized by the SIBAT Team, such as disaster mitigation socialization and disaster mitigation training. The level of community mobilization could be seen in Table 7 .

Table 7. Community Mobilization Criteria

\begin{tabular}{ccccc}
\hline Score Interval & Percentage & Criteria & F & $\%$ \\
\hline $7-8$ & $76-100$ & Very high & 53 & 89,8 \\
$5-6$ & $51-75$ & High & 1 & 1,7 \\
$3-4$ & $26-50$ & Low & 4 & 6,8 \\
$0-2$ & $0-25$ & Very low & 1 & 1,7 \\
\hline & Total & & 59 & 100 \\
\hline
\end{tabular}

Source: Research Results, 2019

\section{Discussion}

The Community-Based Disaster Preparedness Team (SIBAT Team) has a very big role in increasing the resilience of the Kalipancur community against landslides. The SIBAT team is the initiator as well as the core actor in disaster mitigation efforts from the pre-disaster, during disaster, and post-disaster stages in Kalipancur Village. Disaster mitigation efforts carried out by the SIBAT Team include structural mitigation efforts in the form of physical development activities, greening, installing early warning systems, making evacuation routes to non-structural mitigation in the form of socialization activities, simulations, and making emergency response plans. The disaster mitigation education efforts held by the SIBAT Team in the Kalipancur community were not only conceptual but already at the practical level. As a result, the community not only has a high level of knowledge about disasters, but also understands and implements theory through real simulation and prevention efforts.

The SIBAT team plays a major role in empowering the people of Kalipancur to become a community that is resilient to disasters. Empowerment of local communities in disaster mitigation efforts has a very essential urgency in forming a Disaster Resilient Village or Kampung Tangguh Bencana (KATANA) according to government programs. However, local communities are the main stakeholders in disaster risk reduction because they are the ones who 
bear the threat and risk of disasters. For this reason, empowering local communities in disaster mitigation efforts is a strategic effort to maximize the local potential that exists in the community so that it becomes a force that can reduce vulnerability there.

The role of the SIBAT Team in disaster risk reduction in Kalipancur Village is one form of Community-Based Disaster Risk Reduction (CBDRR). Community-Based Disaster Risk Reduction is a process that aims to transform passivity and helplessness into activeness and strength (Luna, 2013 in Sim, Dominelli, \& Lau, 2017). CBDRR is a process in which the community is actively involved in risk assessment, risk reduction implementation, and disaster risk monitoring and evaluation to reduce vulnerability and increase their capacity (Kafle, 2011).

Many other studies have shown the positive impact and effectiveness of the CommunityBased Disaster Risk Reduction program. One of them is in the Beringin River Watershed, Semarang City. The CBDRR program is a strategic solution for people in the Beringin watershed in overcoming floods (Worowirasmi, 2015). Then, there is a difference in the level of community preparedness between before and after the community-based Flood Early Warning System (FEWS) program in the Beringin watershed area. The community-based Flood Early Warning System (FEWS) program there can improve community preparedness in facing flood disasters (Nurrohmansyah \& Setyono, 2014).

The CBDRR program in Beringin Watershed and in Kalipancur Village is a small part of the various CBDRR programs implemented by communities in Semarang City. Semarang City has realised the potential and effectiveness of the CBDRR program since 2012. Semarang City is part of the Asian Cities Climate Change Resilience Network (ACCCRN) which has the vision to become a resilient city. For this reason, the government and the community have always intensified the CBDRR program there. The CBDRR program in Semarang City is realised through community empowerment in the Local Preparedness Group (LPGs) which until 2018 the number of LPGs in Semarang City has reached 35 LPGs, one of which is the SIBAT Team in Kalipancur Village (Wiwandari, et al 2019).

Research results from Kafle (2010) show that CBDRR has enormous potential in empowering people to understand the specific hazards of their environment, understand their vulnerability, and the risk of future disasters that threaten them. Moreover, Sjostedt \& Sturegard (2015) have also conducted research in the Mekong River Delta, Vietnam, and found that CBDRR is an effective model in building a safer society with a higher capacity to face the threat of disasters. The CBDRR program which is implemented in the Mekong River Delta, Vietnam, can be a role model for other countries and various other parties to participate in the program. Research by Lestari, Prabowo, and Wibawa (2012) also proves that communication management during a disaster carried out with a community-based approach is considered to be very effective in accelerating the process of handling the 2010 Mount Merapi eruption disaster during the emergency response.

The positive impact of the CBDRR program is also evident from research from Wulandari, Sagala, \& Sullivan (2018), which reveals that LPGs can play a role in unifying the gap between the community and the government in the information dissemination process. The CBDRR program also not only introduces the community to threatening dangers but also mobilizes the community to contribute directly to various disaster management steps. That way, the risk of disasters that threatens the community will be reduced because the community has prepared appropriate ways to develop community capacity through community management in the processes of planning, organizing, policymaking, cooperation, and control (Salajengheh \& Pirmoradi, 2013). 
Research results from Sarabia, et al. (2020) also stated that disaster risk reduction programs that involve local communities can have a significant positive impact on three important aspects of community resilience, namely knowledge and preparedness, social cohesion, and natural asset management. Then, the CBDRR program is able to provide disaster risk reduction guidance to the grassroots level community. This is important because they are the main parties who feel the direct impact of disasters so they need definite guidance regarding disaster risk reduction in their environment (Lassa, 2018). Fauzie \& Sariffudin (2017) also state that no one can understand the condition of an area except the local community itself, so CBDRR is a strategic step. For this reason, the community must be involved in all aspects of disaster risk reduction to develop their potential and capacity so that they can adapt to the disasters in their surroundings. So, community members can become agents of change to disseminate information to other community members so that a sense of belonging is created to prevent disasters and ensure the sustainability of community life (Rahman, 2018). In addition, the positive impact of CBDRR and community engagement is also proven by research from Cui, Han, \& Wang (2018) and Pfefferbaum et al. (2016).

Based on the research results, it is known that the Kalipancur community has high resilience in facing landslides. This result is quite relevant to the research of Wiwandari et al. (2019) who examined the capacity of people who are members of the Local Preparedness Groups (LPGs) in Semarang City. Of the thirty-five LPGs in Semarang City, the SIBAT Team of Kalipancur Village is classified as a LPG with a capacity level at the top, namely level nine. In their research, Wiwindari et al (2019) measured community capacity by comparing aspects of perception with aspects of evidence with six main frameworks including knowledge, skills or capability, communication and collaboration, financial resources, leadership, and organizational systems. Of the six frameworks, the SIBAT Team of Kalipancur has a capacity value above the average capacity of LPGs throughout Semarang.

The results of Wiwandari's (2019) research are also relevant to the results of this study, stating that LPGs have a very big role in increasing community resilience. This is in line with what was conveyed by Tanwattana (2018) that the formation of a Community Disaster Risk Management Organization (CDRMO) or Community-Based Organization (CBO) is very crucial in promoting CBDRR. This is because CDRMO and CBO are important actors that mobilize the wider community in their environment to play an active role in disaster prevention and preparedness. CDRMO will also enable the CBDRR program to run more systematically and gain strong political and legal support.

The advantages of CBDRR that have been explained above cannot stand alone without cooperation with other parties. The CBDRR program will be very effective if it gets support and cooperation with other parties outside the community, either from the government or NGOs (Tanwattana, 2018; Wulandari, Sagala, \& Sullivan, 2018). The role of the government in efforts to implement the CBDRR program is very important and needed because people cannot move independently without support from the government (Kafle, 2010). Although CBDRR is an effective step in creating community resilience, it still cannot deny the role of the government or other parties such as NGOs (Kapucu, Hawkins, \& Rivera, 2013). The bottom-up based CBDRR program will be very effective if it is also integrated and balanced with a top-down approach (Sim, Dominelle, \& Lau, 2017; Wiwandari, et al., 2019). 


\section{Conclusion}

The SIBAT team has a big role in building community resilience in Kalipancur Village. It has a major role in disaster mitigation education and emergency response efforts whether in the predisaster, during disaster, and post-disaster phases. The magnitude of the role of the SIBAT Team is directly proportional to the level of community resilience in the Kalipancur community. On average, people in Kalipancur have a high level of resilience in the aspects of knowledge, attitudes, actions, policies, emergency planning, early warning systems, and community mobilization.

This research has a lot of relevance with other research, pointing out the magnitude of the positive impact and effectiveness of the role of the Community Disaster Risk Management Organization (CDRMO) or Community Based Organization (CBO) in supporting the implementation of Community-Based Disaster Risk Reduction (CBDRR). This research also shows that the CBDRR program is a strategic effort in building community resilience. The CBDRR program is able to escalate the capacity of communities at risk of disasters to prepare for future disasters and respond to emergencies at the household and community levels and provides guidance for people at the grassroots level.

However, the role and great potential of the CBDRR program cannot continue without the support of various parties, especially the government. The CBDRR program that has been implemented is not only carried out periodically, but must be carried out continuously and passed on to the next generation. The high level of community resilience must be continuously improved and must not be allowed to decline due to the inconsistency of the implemented CBDRR program. For this reason, the role of the government is needed to support the sustainability of the CBDRR program. The government can act as a regulator and facilitator, especially providing sufficient funding because currently, funding is still an obstacle to the sustainability of CBDRR in various regions. Collaboration between the government, NGOs, and communities that combines bottom-up and top-down approaches will be an effective struggle to build community resilience.

\section{Acknowledgment}

We'd like to express gratitude for the Geography Department of Universitas Negeri Semarang and those who were involved in this research, especially people in Kalipancur Village.

\section{References}

Badan Nasional Penanggulangan Bencana. (2012). Buku Saku Tanggap, Tangkas, Tangguh Menghadapai Bencana.Pdf

Badan Nasional Penanggulangan Bencana. (2013). IRBI (Indeks Risiko Bencana Indonesia). Badan Nasional Penanggulangan Bencana. 2017. Panduan Teknis Kelurahan Tangguh Bencana.

Cui, K., Han, Z., \& Wang, D. (2018). Resilience of an earthquake-striken rural community in Southwest China: Correlation with disaster risk reduction efforts. International Journal of Environmental Research and Public Health, 15, 1-14. 
Cummins, P. R. (2017). Geohazard in Indonesia: Earth science for disaster risk reduction Introduction. Geological Society. 441. DOI: 1144/SP441.11.

Fauzie, W. Z. \& Sariffudin, S. (2017). The role local initiatives in community based disaster risk management in Kemijen, Semarang City. 3rd international Conference of Planning in the Era of Uncertainty, IOP Conf. Series: Earth and Environmental Science, 70(2017), 1-12.

Gorsel, J. T. V. (2013). Bibliography of The Geology of Indonesia and Surrounding Areas. Retrieved from Http://www.vangorselslist.com

Haryanto \& Suharini, E. (2009). Preferensi permukiman dan antisipasi penduduk yang tinggal di daerah rawan longsor di Kota Semarang. Jurnal Geografi, 2(6), 73-79.

Kafle, S. K. (2010). Integrated community-based disaster risk reduction: An approach to building disaster resilient communities. Retrieved from https:/www.preventionweb.net/files/ 14348_14348SheshKafleICBRR2010.pdf

Kafle, S. K. (2011). Measuring disaster-resilient communities: A case study of coastal communities in Indonesia. Journal of Business Continuity Planning, 5(3), 315-325.

Kapucu, N., Hawkins, C. V., \& Rivera, F. I. (2013). Disaster preparadness and resilience for rural communities. Risk, Hazards \& Crisis in Public Policy, 4(4), 215-233.

Kurniawan, E. Sriyanto, \& Syifauddin, M. (2019). The academic community capacity of the Universitas Negeri Semarang (UNNES) in dealing with natural disaster. Proceeding of ICESI 2019. DOI 10.4108/eai.18-7-2019.2290116.

Lassa, J. A., Boli, Y., Nakmofa, Y., Fanggidae, S., Ofong, A., \& Leonis, H. (2018). Twenty years of community-based disaster risk reduction experience from a dryland village in Indonesia. Jamba. Journal of Disaster Risk Studies, 10(1), 1-10.

Lestari, P., Prabowo, A., \& Wibawa, A. (2012). Manajemen komunikasi bencana Merapi 2010 pada saat tanggap darurat. Jurnal Ilmu Komunikasi, 10(2), 173-197.

Miles, M., \& Huberman, A. M. (1991). Analisis data kualitatif: buku sumber tantang metodemetode baru. Jakarta: UI Press.

Nurrohmansyah, A. N., \& Setyono, J. S. (2014). Perubahan kesiapsiagaan masyarakat DAS Beringin Kota Semarang dalam menghadapi ancaman banjir bandang. Jurnal Wilayah dan Lingkungan, 2(3), 231-244.

Oktari, R. S. (2019). Peningkatan kapasitas desa tangguh bencana. Jurnal Pengabdian Kepada Masyarakat, 4(2), 189-197.

Parahita, I.K., Luthviatin, N., \& Istiaji, E. (2016). Peran Tim Siaga Bencana Berbasis Masyarakat (SIBAT) dalam kesiapsiagaan bencana di Kecamatan Sumberjambe Kabupaten Jember. Ejurnal Pustaka Kesehatan, 4(2), 345-351.

Pfefferbaum, R. L., Pfefferbaum, B., Zhao, Y. D., Horn, R. L. V., McCarter, G. S. M., \& Leonard, M. B. (2016). Assessing community resilience: A CART survey application in an improvished urban community. Disaster Health, 3(2), 45-56.

Pratiwi, R. D., Nugraha, A. L., \& Hani'ah. (2016). Pemetaan multi bencana Kota Semarang. Jurnal Geodesi UNDIP, 5(4), 122-131.

Rahman, H. A. (2018). Community based approach towards disaster management in Malaysia. Asian Journal of Environment, History and Heritage, 2(2), 55-66.

Salajegheh, S. \& Pirmoradi, N. (2013). Community-based disaster risk management (CBDRM) and providing model for Iran. International Journal of Engineering Research and Development, 7(9), 60-69.

Sarabia, M. M., Kägi, A., Davison, A. C., Banwell, N., Montes, C., Aebischer, C., \& Hostettler, S. (2020). The challenges of impact evaluation: Attempting to measure the effectiveness 
of community-based disaster risk management. International Journal of Disaster Risk Reduction, 49, https://doi.org/10.1016/j.ijdrr.2020.101732

Sim, T., Dominelli, L., \& Lau, J. (2017). A pathway to initiate bottom-up community-based disaster reduction within a top-down system: The case of China. International Journal of Safety and Society Engineering, 7(3), 283-293.

Sjostedt, F., \& Sturegard, V. (2015). Implementation of community based disaster risk management in the Mekong Delta, Vietnam. Lund: Division of Risk Management and Society Safety, Lund University, Sweden.

Suharini, E., \& Kurniawan, E. (2015). Model manajemen terpadu pendidikan kebencanaan berbasis masyarakat. Semarang: Fastindo.

Susanto, N., \& Putranto, T. T. (2016). Analisis level kesiapan warga menghadapi potensi bencana longsor Kota Semarang. Jurnal Teknik, 37(2), 54-58.

Tanwattana, P. (2018). Systematizing Community-Based Disaster Risk Management (CBDRM): Case of urban flood-prone community in Thailand upstream area. Internatonal Journal of Disaster Risk Reduction, 28, 798-812. https://doi.org/10.1016/j.ijdrr.2018.02.010

Undang-Undang Nomor. 24 tahun 2007, tentang Penanggulangan Bencana.

Wiwandari, H., Hapsari, S. P. I., Mega, A., \& Sih, S. J. (2019). Community-based disaster management: Assessing Local Preparadness Groups (LPGs) to build a resilient community in Semarang City, Indonesia. Disaster Advances, 12(5), 23-36.

Worowirasmi, T. S., Waluyo, M. E., Rachmawati, Y., \& Hidayati, I. Y. (2015). The community - based flood disaster risk reduction (CBDRR) in Beringin Watershed in Semarang City. Jurnal Wilayaj dan Lingkungan, 3(2), 131-150.

Wulandari, W., Sagala, S. A. H., \& Sullivan, G. B. (2018). The role of Community-Based Organization in disater response at Mt. Sinabung. The 4th PlanoCOsmo International Conference, IOP Conf. Series: Earth and Environmental Science, 158(2018), 1-11. 